\title{
The Great Aquatic Events of the Plains: Regattas and Rowing in Canterbury, 1850-1890
}

\section{GEOFFREY T VINCENT}

\section{Auckland}

The possibility that organised sport may have facilitated the social development of New Zealand during the nineteenth century has been largely ignored or discounted by historians. The great majority of texts which relate to the period give the impression that life in the Colony was devoid of any sporting activity worthy of mention, or that sport consisted simply of a range of trivial amusements arranged at irregular intervals by settlers with limited leisure time. ${ }^{1}$ A few authors have acknowledged that sport enhanced social cohesion in New Zealand prior to 1900, though most of these have limited their observations to rugby football. ${ }^{2}$ The evidence presented in this paper will suggest that the organised sport of rowing fostered sustained social interaction within and between classes in Canterbury, New Zealand, between 1850 and 1890 .

Rowing became an increasingly organised activity within the British Empire during the nineteenth century. In both England and the principal Australian colonies of New South Wales and Victoria competition centred on formally constituted rowing clubs and regattas. Indeed, the regatta became a prime source of public entertainment in Victorian Britain. ${ }^{3}$ However, the issue of amateurism caused deep divisions in both England and Australia. The main problem was the use of 'mechanics' rules' by clubs and controlling bodies to exclude working-class oarsmen from the ranks of 'true' amateurs, the 'superior strength' of manual workers suuposedly giving them an unfair advantage over 'gentlemen'. ${ }^{4}$ In England opponents of the 'mechanics' rule' separated from the Amateur Rowing Association and formed the National Amateur Rowing Association in September 1890, the sport remaining divided until 1956. Disharmony existed in Australia between the rowing associations of New South Wales and Victoria. The former declined to classify manual labourers as 'bona fide' amateurs, while the latter, perhaps because it functioned in a society in which a strong sense of egalitarianism prevailed, had no qualms about doing so. The two Associations were unable to reconcile their diverging views until $1903 .{ }^{5}$ 
Rowing was among the very first sporting activities organised by the Canterbury settlers, and by 1870 it had engendered a variety of institutions and festivals which were of considerable 'social significance'. Several rowing clubs were established during and after the 1860s, and the Canterbury, Union and Cure Clubs proved to be durable and very strong social organisations (Table 1). Moreover, the regattas held annually from the late 1860s at Lyttelton and Kaiapoi, and in the Heathcote Estuary, became communal festivals which routinely attracted thousands of spectators of all classes. Central to the emergence of regattas as major social events in Canterbury was the expansion of the system of railways and a concomitant increase in the capacity of that division of the rail network devoted to handling passenger traffic.

Table 1 - Rowing Clubs Active in Canterbury 1861-1890

Est. 1861-1870

Canterbury R.C. (1862-)

Union R.C. (1864-)

Cure B.C. (1866-)

Kaiapoi B.C. (1864-70)

Lyttelton B.C. (1864-74)

Planet R.C. (1864-65)

Akaroa B.C. (1864 - ?)

Avon R.C.* (1868- ?)

Ariel B.C. (1866-67)
Est. 1871-1880

Lyttelton Trades B.C. (1870-72)

Timaru B.C. (1876-)

Heathcote R.C. (1870-79)

Christchurch B.C. (1875)

Telegraph B.C. (1875-77)
Est. 1881-90

Canterbury College B.C. (18??-)

Avon R.C.* (1881-)

Akaroa (1881-82)

*Unrelated organisations.

Even the introduction of formal rules relating to amateurism did not diminish the attractiveness of rowing in Canterbury for participants from a wide range of social and occupational backgrounds. Early attempts to introduce restrictive regulations largely failed, and the rules in force throughout the Colony from 1887 were formulated and applied in a spirit of comparative liberality. Thus, the existence of rules relating to amateurism did not lead rowing in New Zealand to become an exclusive or 'closed' sport.

Yet the social inclusiveness inherent in the sport was not infinite, for direct participation in rowing in Canterbury before 1890 was effectively limited to pakeha males. Women were prescribed supporting roles in the aquatic community created and dominated by men. Although the male members of the boating clubs in Christchurch spent many hours early in 1873 organising a bazaar 'in aid of their funds', it was their female relatives who actually provided the labour required to ensure that the venture was 
a success. The wives of eminent local politicians or boating men launched almost every new boat and presented many trophies to victorious crews. In order to 'stimulate ... all rowing men' to greater exertions, women were urged both to become spectators and to create with their skilled needlework prizes of a more personal nature than the materially valuable but tawdry baubles around which competition was generally centred. ${ }^{6}$

By contrast, the close links that the Cure Boating Club (CBC) of Kaiapoi had with the community may have accounted for the special nature of their membership policy. In December 1870 the Club 'decided to admit ladies as honorary members . . . on payment of a subscription of $2 \mathrm{~s} 6 \mathrm{~d}$ each'. The 'names of nine ladies were [immediately] handed in accompanied by their subscriptions'? Unfortunately, the identities of these women remain unknown. This innovation was without significance for rowing in Canterbury more generally. No other club in the Province rushed to emulate the actions of the CBC. Moreover, only in perhaps one instance before 1880 did any newspaper in Canterbury advance the notion that 'rowing . . . as an exercise for ladies, if pursued in moderation . . . becomes an amusement which they ought to patronise'. ${ }^{8}$ The writer almost certainly did not intend to suggest that women should become involved in competitive rowing. Indeed, various authors have observed that the cultivation of muscularity or athletic prowess by women or girls was generally considered both unbecoming and a destabilising influence on the delicate balance between the sexes, and consequently a threat to the social order. ${ }^{9}$ Therefore, females were virtually certain to be denied the chance to become active members in any rowing club in Canterbury prior to 1890.

Maori were also conspicuous by their almost complete absence from rowing in Canterbury during this period. The only effort made by Maori to become involved in the sport on a sustained basis occurred at the Akaroa Regatta, where local hapu competed with some success during the early 1860s. The nature of this involvement, and the factors which precipitated its termination, are subjects that will be dealt with elsewhere. ${ }^{10}$

Rowing as an organised competitive sport first appeared in Canterbury within six months of the arrival of the First Four Ships. A regatta consisting primarily of races between various classes of rowing boat was held on Lyttelton Harbour on 24 May 1851 'in celebration of Her Majesty's thirtysecond birthday'. ${ }^{11}$ Though allowed to lapse through general indifference during the late 1850s, the Lyttelton Regatta was re-established in January 1862 and eventually became perhaps the largest aquatic sporting festival in the Colony.

Rowing in colonial Canterbury generally resembled the sport which contemporaneously flourished in England and Australia, though it also differed significantly from both. The most obvious distinction was the 
absence of the professional sculling which was an integral element of rowing in England, New South Wales and Victoria. Infrequent 'wager-boat' races were held between 'scratch' crews, at which considerable numbers of spectators congregated to support their favourites and to gamble on the result, but the stakes in these contests were generally no higher than $£ 25$ a side, ${ }^{12}$ their modesty suggesting a dearth of backers in Canterbury willing to provide the substantial prize money which would have encouraged the growth of match racing or professional sculling. Though relatively few in number, wager-boat races occasionally had significant consequences for the sport in Canterbury. Following a series of hotly contested matches at Kaiapoi in 1867, this town of less than one thousand inhabitants suddenly found itself with three boating clubs, two of which had been formed by the crews of the challenge boats Cure and Ariel and their enthusiastic supporters. ${ }^{13}$

Even more inhibiting to the development of professional sculling in Canterbury was the shortage of suitable oarsmen. The watermen operating on Lyttelton Harbour offered the only potential cadre of professional scullers in the Province, but circumstances prevented them from performing that role. The geography of the region presented major obstacles, particularly before the late 1860s. The watermen were isolated by the Port Hills from the centre of population which could have regularly provided large numbers of spectators prepared to gamble on boat races. By December 1867, when the Lyttelton Railway Tunnel opened to passenger traffic, three regattas and several rowing clubs had already been established, but most of this activity was north of the Port Hills, in Christchurch and Kaiapoi. Thus, the sporting public had been provided with an alternative aquatic entertainment to professional sculling. Moreover, the environment in which the watermen worked was an area of semi-enclosed ocean, one quite unsuitable for racing the sleek, flimsy 'fresh water' boats used by professional scullers. ${ }^{14}$ No recourse was possible in Lyttelton to the comparatively smooth, sheltered waters of a river. The final complication was that, just as in England, the watermen were a dying breed. No more than fifty-four watermen were operating at the port in 1874 , and the numbers declined rapidly thereafter. ${ }^{15}$ Many of those who remained in business abandoned the oar in favour of new technology such as the steam launch. ${ }^{16}$ In short, Canterbury lacked the money, facilities and personnel required to cultivate professional sculling.

However, in most other respects rowing in the Province closely resembled the highly-developed sport which existed in England, New South Wales and Victoria. Competition was centred on 'the Regatta' and, increasingly from 1870, the formally constituted 'Club'. Nevertheless, the sport in no way conformed in every particular to the ideal articulated by the ARA in England. Rowing in Canterbury was characterised by an attitude towards 
amateurism resembling that prevailing in Victoria, rather than the narrower and more exclusive outlook in England and New South Wales.

By 1870 competitive rowing in the Province principally consisted of crews of ostensible 'amateurs' from formally organised clubs racing against one another at a number of regattas held in close proximity to Christchurch. However, determining the precise nature of the membership of these clubs is complicated by the sources available for occupational identification. Four limitations are inherent in the electoral rolls of the period. For a start, the rolls do not contain information concerning club members who were under the age of legal adulthood. Secondly, those who had attained majority, but who chose not to register, do not appear on the rolls. Moreover, not every male who was twenty-one and who wished to register met the requirements regarding property or annual rent which enabled him to qualify for the privilege. The final difficulty is that no information on the occupations of those who registered to vote was included in the rolls published between 1860 and 1879.

The Canterbury Rowing Club (CRC) was unique in the Province, being an 'exclusive' or 'closed' organisation. Aspiring members had to be nominated by an existing member and elected at a General Meeting of the club, 'one black ball in four' being sufficient to ensure exclusion. ${ }^{17}$ This mechanism ensured that the club became a means of fostering solidarity within the urban élites and consolidating the ties amongst young white-collar workers deemed worthy of membership. Table 2 presents information regarding the forty-seven individuals who can be identified with certainty among fiftyeight recorded in various sources as being members of the CRC during the 1868-69 season. Twenty-six were drawn from the urban and rural élites. Among the seven professionals were three prominent Anglican clergymen, one of whom, the Reverend E.A. Lingard, was elected Club Captain for the 1869-70 season. The remaining twenty-one men were members of the middling classes, all but two being employed in some form of clerical occupation..$^{18}$ The conspicuous absence from Table 2 of members engaged in blue-collar occupations is not simply an artefact of a reliance upon 'classbiased' sources in which working-class people are all but invisible. The data relating to the 1879-80 and 1889-90 seasons, compiled from sources which enable the identification of manual workers, demonstrate that the number of working-class members remained tiny after 1879. Consequently, because the factors which facilitated the participation of the working-classes in sport were gaining strength, it is reasonable to conclude that the CRC and any other clubs with few working-class members after 1879 had very few or none during the preceding years. 
Table 2 - Canterbury Rowing Club Membership 1868-90

Occupational categories

1868-69

1879-80

$1889-90$

I: Elites

(a) Professionals

7

(b) Major rural proprietors

5

(c) Major urban proprietors, managers and officials

II: Middling Classes

(a) Clerks and salesmen

16

3

(c) Petty rural proprietors and farm managers

(d) Petty urban proprietors, managers and officials

III: Blue-collar Workers

(a) Skilled

(b) Semi-skilled

(c) Unskilled and menial service workers

Total

47

45

21

13

$18 \quad 20$

2

$0 \quad 1$

$3 \quad 3$

$\begin{array}{lll}0 & 2 & 2\end{array}$

$\begin{array}{lll}0 & 0 & 1\end{array}$

$\begin{array}{lll}0 & 1 & 1\end{array}$

45

43

The evidence presented in Table 2 indicates that the social structure of the CRC changed very little throughout the next decade. Use of the Electoral Rolls published in 1879, which were the first set since those compiled in 1860 to include occupational information on voters, has permitted the accurate identification of forty-five of the seventy-four individuals who were registered as members during the 1879-80 season. Nineteen members were drawn from the élites. Twenty-three others were members of the middling classes, ${ }^{19}$ sixteen of them being employed in clerical positions. Only three were engaged in blue-collar callings - a shipwright, a tailor and a cabman. ${ }^{20}$

Those who remain anonymous probably fall into two groups. The first is made up of members who were under twenty-one years of age when the Electoral Rolls published in 1879 were in the process of being compiled. The second comprises those who were politically apathetic, or who were unable to meet the residence qualification for voting because they had recently changed address or led itinerant lives. Blue-collar workers were probably somewhat over-represented in the latter group, at least until the late 1880 s, but this over-representation can hardly have been great enough to cast doubt on the trend of élite and middling-class dominance suggested by Table 2 . 
The data provided indicates that the CRC remained almost exclusively an enclave of the élites and the middling classes throughout the 1880s. Sufficient information can be obtained, particularly from the Electoral Rolls, to permit the identification with reasonable precision of forty-three of approximately one hundred individuals listed as members during the 188990 season in the official history of the club. Of those identified, thirteen were drawn from the ranks of the élites, including the Surveyor of the City of Christchurch and three senior Anglican clergymen. A further twenty-six members worked in a wide variety of low white-collar occupations. The remaining four were blue-collar workers - an engineer, a compositor, a musician and a fishmonger's assistant. ${ }^{21}$

Thus, prior to 1890 the membership of the Canterbury Rowing Club was apparently drawn overwhelmingly from the urban élites and white-collar middling classes. Certainly, many members could not be identified but, as noted above, this is most unlikely to threaten the overall conclusions.

Its élitism notwithstanding, the CRC worked to become a competitive sporting entity. The number of members stabilised at approximately 150 during the 1870s. The club was not of itself very wealthy, but it was administered soundly, and was therefore able to purchase boats regularly from Salter of Oxford in England, and from builders in Melbourne, Sydney and Lyttelton. ${ }^{22}$ Members also trained regularly and the representative crews were coached assiduously by Reverend Lingard until his departure for England in September 1870. The CRC competed at almost every regatta, particularly from the mid-1870s under the energetic captaincy of J.O. Jones, though perhaps without achieving the level of success which might have been expected from a club of its comparative wealth and size.

'Open' clubs, such as the Union Rowing Club (URC) and Cure Boating Club, were more common in Canterbury. The URC was initially formed in September 1864 as the Railway Rowing Club (RRC), with membership restricted to white-collar employees of George Holmes and Company, the firm responsible for constructing and operating the rail system in Canterbury until July 1868. However, the RRC was declared 'open to all comers' in August 1866, and any overt intimation of its origins was effectively removed in September 1869 when the name of the club was changed from Railway to Union. ${ }^{23}$ The entrance fee was set at $£ 11$ s from September 1876, a figure which was 'found beneficial and in no way deterrent to those desirous of becoming members'. ${ }^{24}$ This assertion appears to have been accurate. The URC gradually evolved from a relatively small 'closed' club, the membership of which was drawn primarily from the urban élites and middling classes, into an 'open' club which attracted oarsmen from many social backgrounds. However, while the social composition of the URC altered over time, the magnitude of the shift cannot be precisely ascertained because an 
indeterminate proportion of the membership of the club, particularly those who were young or blue-collar, remains virtually invisible.

Table 3 contains information relating to forty-four individuals who can be positively identified among the fifty-seven members of the Union Rowing Club during the 1868-9 season. Twenty-six were members of the urban and rural élites. Among the prominent members of the club were Edward Jollie, the Provincial Secretary, Provincial Auditor John Marshman, and John Ollivier, who served as both Speaker of the Provincial Council and Provincial Auditor. The remaining eighteen members were drawn from the middling classes and included clerical workers, the owners of small businesses and minor officials. ${ }^{25}$

Table 3 - Union Rowing Club Membership 1868-90

Occupational categories

1868-69

1879-80

$1889-90$

I: Elites

(a) Professionals

(b) Major rural proprietors

6

(c) Major urban proprietors, managers and officials

II: Middling Classes

(a) Clerks and salesmen

(b) Semi-professionals

(c) Petty rural proprietors and farm managers

$\begin{array}{lll}6 & 1 & 1\end{array}$

300

17

4

2

(d) Petty urban proprietors, managers and officials

$\begin{array}{lll}5 & 8 & 10 \\ 2 & 0 & 0 \\ 0 & 0 & 0 \\ 11 & 5 & 6\end{array}$

III: Blue-collar Workers

(a) Skilled

$\begin{array}{lll}0 & 2 & 3\end{array}$

(b) Semi-skilled

0

(c) Unskilled and menial service workers

0

44
1

3

24
10

0

0

6

3

2

1

25

The data presented in Table 3 suggests that the social composition of the Union Club changed significantly during the 1870s. The élites which had formed the majority of the membership in 1868-69 were no longer present a decade later. The relevant sources, especially the Electoral Rolls, yield sufficient information to enable the identification of twenty-four of about seventy persons listed as members during the 1879-80 season. Five of those identified were members of the urban élites, while another thirteen were drawn from the urban middling classes. The six identifiable members employed in blue-collar vocations included an engineer, a carpenter, a 
bacon-curer, a labourer, a wool-sorter and a coachman. The extent to which the URC was an 'open' organisation is demonstrated by the fact that the coachman in its ranks was C.F. Bowley, one of the most active 'pedestrian' athletes in Christchurch. Nobody involved in such activities would have been allowed to join any club affiliated to an Amateur Rowing Association in England or Australia during these years.

Based on the evidence available, the composition of the Union Rowing Club appears to have stabilised during the 1880s. Only twenty-five from among a reported membership of 165 during the 1889-90 season can be definitely identified, a circumstance which photographic evidence suggests might be closely related to the large number of young members in all rowing clubs during this period.

The three members included in the category of élites were all prominent businessmen and included John Anderson, owner of the largest iron foundry in Christchurch. The sixteen members drawn from the ranks of the middling classes were principally clerical workers or owners of small businesses. Among the six employed in various blue-collar jobs were a carpenter, a brassfounder, a paper-ruler, a coach-builder, a hotel employee and a warehouseman.

Thus, the social configuration of the URC changed significantly between 1870 and 1890. Like their counterparts at the CRC, most of those members of the URC during the 1879-80 and 1889-90 seasons who remain anonymous were probably absent from the Electoral Rolls for the reasons elaborated above.

Arguably, the membership of the URC also increased numerically from the late 1870s. Prior to the end of 1877 the club maintained a strength of approximately forty active and ten honorary members each season. ${ }^{26}$ However, the total increased to seventy-one in August 1878, 117 in 1880 and 165 in September 1890. ${ }^{27}$ Thus, within approximately twenty years the URC had developed from a comparatively modest organisation dominated by members of the urban élite into a large 'open' club which drew members from all occupational groups.

The Cure Boating 'Club' situated in Kaiapoi was always small, averaging fewer than twenty members in any season. The élites, clerks and salesmen were totally absent from the ranks of this diminutive club. Twelve of those who were members during the 1868-69 season can be positively identified. Six were the proprietors of small businesses in the town of Kaiapoi - two hotelkeepers, two storekeepers, a builder and a boat-builder. The two members who owned small rural enterprises were a sheepfarmer and a dairy farmer. Among the four employed in blue-collar vocations were two blacksmiths, a carpenter and a bootmaker. ${ }^{28}$ The nine members from the 1879-80 season who are identifiable comprised a farmer, one who combined 
the occupations of breeder of Clydesdale horses and ploughman, another who worked as both farmer and butchery proprietor, a carpenter, an apprentice carpenter, a ropemaker, a wheelwright and two labourers. ${ }^{29}$

The CBC also placed great emphasis upon remaining competitive. Kaiapoi was reputedly a hamlet in which 'every one appears . . . to take a more than lively interest in boating matters' ${ }^{30}$ The inhabitants resembled their counterparts in many small towns throughout the north of England who demanded, in defence of municipal pride, that their 'indigenous talent' be converted into an 'enthusiastic machine' capable of 'tussling with the best' in the relevant sport. ${ }^{31}$ Whatever the ultimate motivating factor, the $\mathrm{CBC}$ enjoyed success in competition out of all proportion to its size.

By contrast, the competitive ethos which prevailed within and between the metropolitan clubs in Canterbury was seldom sufficiently strong to induce their participation in regattas held outside the Province. Christchurch, wrote an anguished STROKE in 1876,

has not been represented at any of the interprovincial regattas for some years, whilst Auckland, Wellington, Hokitika, and even Kaiapoi - all of which towns possess rowing clubs vastly inferior to our own, both as to number of members and also number and quality of boats - have been represented on most, if not all, occasions. ${ }^{32}$

Several considerations may have combined to produce this situation. STROKE allegedly asked a leading member of the Canterbury Rowing Club ('a good oarsman'), why he did not form a crew for the interprovincial regatta to be held in Nelson. The 'oarsman' replied, somewhat disingenuously in view of the energy expended by the CRC at regattas held within Canterbury, that 'all he cared for was to take a quiet pull with his lady friends'. ${ }^{33}$ This response perhaps indicates a simple reluctance to undertake arduous journeys in predominantly 'wind-driven coastal shipping' along the 'external and unreliable saltwater highway ${ }^{34}$ simply to row a couple of races in uncertain conditions. Any 'boating men' wishing to attend regattas in other provinces would also presumably have experienced difficulties in obtaining sufficient time away from work.

Moreover, as the letter from STROKE implies, the oarsmen of Canterbury considered that they already constituted 'the strongest boating circle in New Zealand, both numerically and financially'. ${ }^{35}$ A conviction probably took hold that, with rare exceptions such as the Star Boating Club in Wellington, the strongest opposition in the Colony was to be found locally. The general acceptance of such a belief by 'Christchurch rowing men' may have curbed any inclination, at least until the late 1880 s, to travel further afield in search of competition.

Finally, the expense inherent in transporting contestants and their craft around the Colony, which was undoubtedly heavy and unlikely to 
be recovered unless victory could be achieved, presumably constituted a significant disincentive to competition in other provinces. ${ }^{36}$ The officials in charge of railways in Canterbury were usually willing to arrange the carriage of competitors and boats free of charge to events held within the Province, perhaps because the large number of passengers carried to and from regattas generated handsome profits. However, because they could expect no similar windfall in passenger traffic, the management of the private companies which operated the shipping services between the main centres of European population seldom proved so amenable in the matter of transporting crews and equipment from one part of New Zealand to a regatta held in another. Only when clubs accumulated sufficient wherewithal during the early 1880 s did they regularly attempt to compete in regattas, or to establish consistent rivalries with clubs located in centres outside the province. ${ }^{37}$

The financial constraints under which the rowing clubs of Canterbury operated before 1890 not only limited their ability to compete in other parts of the Colony but also constituted a threat to their survival, consequently stimulating them to be as successful as possible at regattas held within the Province. Indebtedness was common throughout the sport. The CRC and, to a greater extent, the URC both operated in overdraft during the 1870s. Only the possession of assets with an estimated value of several hundred pounds lent them the appearance of being 'in the black'. ${ }^{38}$ The Cure Boating Club frequently borrowed money from Charles Oram, the landlord of the Pier Hotel in Kaiapoi and a stalwart member of the club. At other times money was raised by 'disposing of sufficient of the club's property' and by raffling 'the boats Undine and Cure for . . £10' in order to avoid collapse. ${ }^{39}$ G.H. Wearing told one meeting of nervous members that 'every club in Canterbury [is] more or less dependent on its winnings at the regattas to help its finances out'. ${ }^{40}$

All of the clubs attempted to avert insolvency and supplement any income derived from prize money won at regattas by holding 'entertainments', which involved members and their supporters acting, singing or playing 'musical selections' before audiences who were charged for admission. ${ }^{41}$ Most of these theatrical events generated limited financial returns. ${ }^{42}$ That they were necessary reinforces the impression that the situation of rowing clubs in Canterbury remained precarious, the majority being forced to resort to a variety of shifts and contrivances in order to survive until they began to accumulate substantial assets during the late 1870s.

Ultimately, however, it was the regattas which, through the prize money offered in the various races, provided clubs with a major portion of their income, making them central to competitive rowing in Canterbury between 1850 and $1890 .{ }^{43}$ A regatta was also a major public event, attracting 
spectators from throughout the Province. Initially, as in Australia, regattas were principally festive occasions. In 1858 the Lyttelton Times described the Lyttelton Regatta as an 'annual festivity . . . originally held on the Queen's Birthday ... rather than a sporting event'. ${ }^{44}$ Although after 1868 the ceremonial aspects of regattas were primarily confined to the various Opening Days of the rowing season in Lyttelton, Christchurch and Kaiapoi, they continued to serve as occasions for celebration. From 1862, the year of its resuscitation, the Lyttelton Regatta became the affair around which the port's New Year's Day celebrations centred. Despite the inconvenience of having to travel by rail from Christchurch to Ferrymead, and then either traverse the Port Hills or journey by sea around Bank's Peninsula, growing numbers of 'holiday people' came from the city to participate in the revels. ${ }^{45}$ The opening of the Lyttelton Railway Tunnel in December 1867 transformed the relative trickle into a flood. Just two weeks later 'upwards of 3000 people came from Christchurch by train' to enjoy the regatta of 1868 . The number of visitors rose to almost 6000 in 1873, and over 8000 in $1876 .{ }^{46}$

Though the Kaiapoi Regatta was held annually from 1868, it was never scheduled to coincide with a specific holiday. The inaugural event was held on New Year's Day 1868, that of 1872 was held on Boxing Day, and those of 1875 and 1879 on St. Patrick's Day. The regatta was usually arranged when a high tide on the Waimakariri River could be guaranteed. ${ }^{47}$ The irregularity of its timing did not prevent the Kaiapoi Regatta from becoming one of the most popular annual sporting events in Canterbury. An estimated ' 1500 to 2000 spectators' attended the regatta in 1868, and 'about 1000' in 1870. The opening of the rail link with Christchurch in April 1872 prompted the general belief in Kaiapoi that 'the forthcoming regatta would be a very successful affair'. This optimism was fully justified, for of the '2500 persons' who visited the town, 1500 arrived by train. ${ }^{48}$ The influx of pleasure seekers on such occasions more than doubled the population of the town, which stood at only 868 in 1871 and 1002 in 1874 . Newspaper reports of every regatta held thereafter emphasise the importance of the numerous spectators brought by the railway in making the event a success.

The timing of the Heathcote Regatta was similarly irregular. The 'great aquatic event of the Plains' was held at various times, including Boxing Day, Canterbury Anniversary Day, and on any other day between mid-December and March considered convenient for the participants. Sited adjacent to the largest concentration of population in Canterbury, the regatta had a strong appeal. 'Christchurch seemed literally deserted yesterday', wrote one reporter who attended the inaugural event,

and the officers of the railway have never had, and for some time perhaps never will have, so much work on their hands. Trains left the Christchurch station about every forty minutes, lodging their freight at 
the Heathcote . . . The crush around the entrance of our station was painful to witness, and still more painful to experience. ${ }^{49}$

Having arrived at the site of the regatta the 'visitors . . . swarmed upon the bridge and covered the hill side with picturesque and animated groups'. ${ }^{50}$ However, by the late-1870s attendances at the regatta were declining in the face of competition from other public 'amusements of all kinds' which flourished in the metropolitan area. ${ }^{51}$

The factors which helped popularise regattas as important social events fall into two broad categories. Firstly, deliberate steps were taken to encourage the participation of the greatest possible number of the population, 'especially the humbler classes', in the day's activities. A public holiday was usually arranged, either by the Provincial Government or by the local business community. Confectioners and publicans erected tents from which many varieties of 'refreshment' were available, and each invariably 'did a rattling business'. Brass bands were also ubiquitous. ${ }^{52}$ 'There were also, as usual on such occasions', noted one observer, 'several games, presided over by persons who made a profit out of the appetite for hazard, which, in some minds, seems to be almost as strong as that for food'. ${ }^{33}$ The boat races themselves 'excited a very large amount of . . . speculation', with bets 'briskly laid, sweepstakes got up', and large amounts of money changing hands. ${ }^{54}$ In addition programmes of rural sports and games, organised for both adults and children, offered entrants the chance to win substantial prizes in cash. These were expected to lure a wide variety of competitors.

A variety of reasons attracted the Provincial élites to the regattas. Many of them were Englishmen of middle-class background who had been involved in rowing 'at Home'. ${ }^{55}$ The involvement of the economic, social and political élites was essential to the success of the occasions. These groups arranged the public holidays, assisted with the organisation of the regattas and most of the associated activities, and provided through public subscriptions the bulk of the funds required for the prizes and to defray general expenses. Being thus engaged in a regatta provided the élites with an opportunity to "prove their credit while they took their pleasure'. ${ }^{56}$ They may also have benefited through the creation of new relationships of possible future advantage in other fields of endeavour, or by the intensification of those previously established in the course of business, marriage or political activity.

Although the élites frequently predominated within the committees which organised regattas in Canterbury, pragmatism always dictated that some members be drawn from other classes. For instance, the committee which administered the Lyttelton Regatta in 1869 consisted of thirty-one members, of whom twenty-two can be positively identified. Sixteen were members of the urban or rural élites. All, with the exception of the Harbour Master at Lyttelton, were the proprietors or managers of major commercial 
or agricultural enterprises. Five others were members of the middling classes, being either employed in low white-collar callings or the proprietors of small businesses. Only one member of the committee, a licensed waterman who worked at the port, can be identified as a blue-collar worker. ${ }^{57}$

The magnitude of the contribution made by any individual to the successful conduct of the regatta was not necessarily related to social status or occupation. Some were undoubtedly invited to join the committee because of their intimate knowledge of the conditions which prevailed on the harbour. George Messiter, the solitary professional waterman on the committee, and his colleague Thomas Ockford, who had followed the same calling at Lyttelton for several years before becoming a publican at Akaroa, presumably offered invaluable advice on the design of the courses over which the various events were to be held. Thus practical considerations determined that the Lyttelton Regatta committee would be composed of men drawn from a range of occupational backgrounds.

This situation remained constant over time, though the scale and importance of the undertaking increased dramatically. The committee which organised the Lyttelton Regatta in 1880 consisted of 109 members, ninetythree of whom can be identified with certainty. Seventy-five were members of the élites, constituting a melange of 'major proprietors, managers and high ranking officials'. ${ }^{58}$ Fifteen others were drawn from the middling classes, being either the owners of small businesses or individuals pursuing a range of clerical vocations. Only three members can be linked to blue-collar occupations. The number of those invited to join the committee because their participation would be of direct benefit to the regatta, and the variety of their occupations, had increased dramatically. Among the members were seven master mariners, two harbour masters, two 'master stevedores', a marine pilot, a ships' chandler, a journalist, and William Reeves, the proprietor of the Lyttelton Times and an enthusiastic supporter of sport in Canterbury. ${ }^{59}$

The committees which organised the regattas held annually at Kaiapoi tended to be dominated by local businessmen, though they always incorporated a higher proportion of members selected because of their evident utility than the analogous bodies at Lyttelton. This latter circumstance arose principally because the committees at Kaiapoi were chosen from a comparatively small population. The committee which arranged the Kaiapoi Regatta in 1869 consisted of sixteen members, eleven of whom can be positively identified. Three, including two professionals and an official, were drawn from the ranks of the élites. However, the status of the 'professional' in Kaiapoi was scarcely comparable to that of the leading professionals in Christchurch. Kaiapoi did not have a cadre of élites corresponding to that of Christchurch. The remaining eight members comprised five petty urban proprietors, the 
owner of a small sheep farm, the manager of the local branch of a bank and a municipal official. ${ }^{60}$ At least five of the committee were selected primarily because their skills and experience could be used to immediate advantage. All were active members of the Cure Boating Club in Kaiapoi and therefore familiar with the course on the highly unpredictable and flood-prone Waimakariri River over which the regatta was rowed.

Twenty-two members served on the committee which managed the regatta in 1880. All but one can be definitely identified. Five were drawn from the élites. Twelve others were from the middling classes, an amalgam of petty urban and rural proprietors and minor officials. Three of the committee were employed in skilled blue-collar trades, while the two remaining laboured in unskilled blue-collar vocations. Practical concerns apparently played a significant part in the selection of three members. J. Lowthian Wilson, journalist and agent in the Kaiapoi district for The Press, was especially useful for the opportunities at his disposal to keep the regatta and those involved in its organisation before the public. Equally serviceable to the committee were R.H. Mathews, the leading boat-builder in Canterbury, who had constructed craft for most of the clubs in the Province at his yard in Kaiapoi, and Frederick Pearce, a carpenter with experience in the construction of boats. ${ }^{61}$ Thus, many individuals were able to make a practical contribution to the successful conduct of a regatta, irrespective of their social status or occupation.

The involvement of political leaders put the seal on regattas as important social events. From the late 1870 s the committees which arranged the regatta at Lyttelton routinely included at least one Member of the House of Representatives, as well as the Mayors of Akaroa, Christchurch, Kaiapoi and Sydenham. Among those who inevitably served on the corresponding bodies at Kaiapoi were the Mayor and the Town Clerk, while Dr Charles Dudley, the 'uncrowned king of Kaiapoi', served as Commodore until his death in 1884. The presence of the leaders of government, whether local, Provincial or General, implied that the regatta had become established as an important social institution. From the early 1860s the Superintendent of the Province filled the highest post in both the Lyttelton and Heathcote Regattas, acting either as Patron or Commodore, and the Provincial Government subsidised the meets at Lyttelton and Kaiapoi. ${ }^{62}$ The railways, under the control of both the Provincial and General Governments, organised more frequent services on regatta days, offering heavily discounted fares and occasionally carrying without charge the boats belonging to competitors. ${ }^{63}$

It is likely that the involvement of the political élites was motivated, at least to some extent, by self-interest. Individuals holding or running for elected office may have been tempted to associate themselves with the organisation of sporting activities bringing enjoyment to thousands through a 
desire to portray themselves to the public as benefactors and thereby gaining some advantage over their opponents. In an unusually overt display of such behaviour W.S. Moorhouse and J.D. Lance, two of the rival candidates for the Superintendency of Canterbury in 1866, respectively offered prizes of $£ 15$ and $£ 10$ in events open only to watermen at the Lyttelton Regatta. ${ }^{64}$ Most politicians in Canterbury in the years before 1890 appear to have been more circumspect in attempting to garner support through their involvement in regattas or other popular sporting events.

An increasing number of individuals with experience in the management of rail transport were invited to join the committee which arranged the Lyttelton Regatta. These experts were initially drawn from private companies, later from the responsible organs of the state. Few people were more conversant with the railways in Canterbury in 1869 than the contractor George Holmes and runholder Edward Richardson, partners in the firm which had originally constructed and managed the entire enterprise, including the Lyttelton tunnel. ${ }^{65}$ The presence of Holmes and Richardson on the executive was an overt acknowledgement by the remaining members of the growing importance of the 'steam-horse' 66 as a means of carrying competitors and spectators between Christchurch and the port. A decade later the Lyttelton Regatta committee contained at least seven men who were then, or had previously been, heavily involved in the management of Canterbury's railways. The group included the Commissioner of New Zealand Railways (NZR) in the South Island, the General Manager of the NZR in Canterbury, the first General Manager of the defunct Canterbury Provincial Railways, leading civil and mechanical engineers, and the clerks who organised tickets at the stations in Christchurch and Lyttelton. ${ }^{67}$ The inclusion on the committee of such a comprehensive array of expertise in the organisation of rail transport clearly demonstrates just how central the railways had become to the success of the regatta by 1880 .

The majority of those who organised the various regattas were aware of the importance of prize money for the survival of clubs, and believed that competitors were motivated by the desire to obtain material rewards rather than by the conviction that 'victory should be its own reward'. ${ }^{68}$ Although purses had been competed for from the time aquatic sports had been established in Canterbury with the first Lyttelton Regatta in 1851, the offer of trophies and cash prizes grew apace from 1864. The programme for the Heathcote Regatta in that year listed nine events, and the prizes amounted to $£ 71$ in cash and $£ 40$ in trophies. The value of individual awards ranged from $£ 2$ to $£ 25$. In 1877 the committee organised six races, for which money prizes to the amount of $£ 52$ and three cups of indeterminate but considerable value were offered. ${ }^{69}$ The inaugural Kaiapoi Regatta consisted of only five races. The aggregate value of the prizes was $£ 3610$ s, including 
cups worth $£ 5$. Single prizes varied between $£ 110$ s and $£ 20$. By 1875 the programme had been expanded to include seven races, and the sum offered in prize money totalled over $£ 80$. Prizes were worth a minimum of $£ 210$ s and a maximum of $£ 25 .^{70}$ Furthermore, the incidence of fouling appears to have increased over time, particularly in races for which large purses were offered. ${ }^{71}$ This tendency apparently caused concern in some quarters. Appended to the rules of the second Heathcote Regatta is a definition of fouling which resembles a catalogue of the sharp practices for which professional scullers were notorious in England. ${ }^{72}$

As in Australia, the organisers of regattas in Canterbury encouraged the participation of working oarsmen through the organisation of events designated as being for watermen and 'open to all comers'. Entry to other races was restricted to amateurs or youths under a nominated age. ${ }^{73}$ Thus the 'amateur' competitors, increasingly associated with rowing clubs, were carefully separated from the 'professionals'. Organisers were probably motivated in their actions by the wish to make regattas as socially inclusive as possible, but they nevertheless shared the prevailing belief in English rowing that those who rowed for pleasure and exercise should be 'protected' from the rigours of competition with others who rowed for a living.

This attempt to keep a distance between the two categories of oarsmen reflected the underlying hostility among amateurs towards their 'professional' counterparts. 'Amateur' oarsmen attempted on two occasions to improve their own chances of winning valuable trophies and prize money by seeking to introduce rules under which 'professionals' would be eliminated from competition. The definition of a 'professional' which was espoused in the first instance differs markedly from that adopted six years later. In September 1866 the Heathcote Regatta Committee proposed inaugurating an 'Interprovincial Champions Race' for amateur coxed fours, for which a trophy worth $£ 50$ and prize money of 100 sovereigns would be awarded. The committee resolved, on the motion of John Ollivier, that 'no person should be considered an amateur for the Heathcote inter-provincial match of 1866, who had plied for hire, or been professionally engaged as a waterman, within six months from the date of entry'. A 'memorial' protesting against this interpretation was subsequently addressed to the committee by 'most of the rowing men in Christchurch, including many who have belonged to the two University clubs and other principal rowing clubs in England'. The petitioners declared that "no person should be considered an "amateur" who has ever held a waterman's license or plied for hire' and implored the committee to reconsider its decision. Opinions were freely expressed in the newspapers that the committee's definition would be entirely unacceptable at Henley or in 'the amateur races on the Thames', and that it would 'admit a great many ... professional men ... and no doubt deter amateurs from other 
provinces from entering the race'. The committee, however, was unmoved and the conditions of the race remained largely unaltered. ${ }^{74}$

The basis for this hostility emerged fully in February 1872, when the Regatta again became the centre of controversy. There appeared on the programme in that year an event for a 'Pair-oared Race' which was open to all members of Rowing Clubs in the Province of Canterbury 'who do not get their living by bodily labour'. The Challenge Cup was offered by W.C. Maxwell Esq. and valued at $£ 18$ 10s. ${ }^{75}$ Maxwell's belatedly announced intention was to induce the office-bound members of boating clubs to become more active in the sport by providing an event in which they could gain the confidence required to confront the 'experienced oarsmen whom they . . . think so formidable'.$^{76}$ Although an identical event had aroused no comment in 1871, an acrimonious discussion now erupted in the letters pages of the local newspapers over the fairness or otherwise of a 'mechanics's rule'. An outraged Cantab thought that,

strictly interpreting the conditions laid down, no mortal creature will be able to compete. Bank and merchants' and Government clerks form the bulk of the clubs. Are they excluded? . . . Is Jack Deal, carpenter, who undoubtedly gets his living by 'bodily labour', to be excluded, while Septimus Noodle, Esq., who gets his living by mechanically copying a few figures into a ledger - under constant supervision - is admitted? . . . Both get their living by 'bodily labour', with this difference - Jack Deal requires brains for his work, while Septimus Noodle, Esq., requires none.$^{77}$

If the rule had been formulated to exclude crews made up of working-class oarsmen, then 'farewell all good feeling, farewell the cultivation of manly sports merely for their own sake, and farewell that fairplay itself which Englishmen boast so much about'. 'Let there be no CLASS restrictions', demanded 'Cantab', 'let it not go out to the world that we are tainted with SNOBOCRACY' ${ }^{78}$

While some endorsed 'Cantab's' view, others supported the introduction of a 'mechanic's rule'. 'Is there no difference,' asked 'Cantabury', 'between the physical power' of clerical workers 'who can only steal the night and morning hours for practice, and the hardy sons of toil', particularly watermen, whose muscles are strengthened by repetitive physical labour? 'Cantabury's' 'hardy son of toil' was 'what is commonly understood by the word "handicraftsman" - a man who obtains his living by manual labour, such as carpenters, boat-builders, licensed watermen, builders, founders, and the like - men skilled in muscular and mechanical or manual and bodily labour' ${ }^{79}$ A crew composed of manual labourers should not be permitted to enter the race, for they would certainly defeat any drawn from 'men cooped 
up in their offices'. Such an outcome, argued 'Cantabury', would frustrate Maxwell's intention of providing that category of oarsmen who had 'done the most for . . . boating in Canterbury' with a prize for which only they might compete. The exercise of common sense in deciding whether any particular individual was a 'handicraftsman' would ensure that 'we need be under no serious apprehension of finding crews enough to compete'. $\mathrm{He}$ accused 'Cantab' of pandering to 'the "Jack Deals", and endeavouring 'to create a schism between the classes where none exists - to foment ill-feeling where harmony and good-will do and should ever prevail', ${ }^{80}$

'One of the Soft-Handed' attacked the rationale underpinning the 'mechanic's rule'. He considered 'that men employed in banks or other offices, who have more time to practise [and] go to their evening exercise comparatively fresh, instead of being tired out after a long day of manual labour, have rather an advantage over carpenters and other mechanics'. 'True', he admitted, 'their hands may not be as hard, but their muscles can be as strong if they will train properly, for which they have more time and opportunity than the mechanics ${ }^{81}$ Some oarsmen were confused. One wished to know whether, 'being a shopkeeper, I would be allowed to form one of a competing crew? I don't know whether I get my living by "bodily labour" or not. ${ }^{82}$ These views were prompted by a social reality in which the liberal notion of equal opportunity was not hampered by a class structure of the English type.

The tumult eventually subsided and the race was rowed under the conditions originally laid down by Maxwell, though the inflammatory restriction was quietly dropped from the conditions of entry at later Heathcote Regattas. ${ }^{83}$ The entire episode was probably an attempt by Maxwell to 'smuggle' in a ban on a 'class' (those who live by 'bodily labor') with the justification of defending 'inexperienced' oarsmen against 'experienced' oarsmen. During the 1880s the definitions of amateurism became less ambiguous. The strength of opinion which existed on this issue in the various provinces became abundantly clear during the mid- and late-1880s during the 'often bitter and acrimonious process' of establishing the New Zealand Amateur Rowing Association (NZARA) ${ }^{84}$ As Eddie Martin has recently shown, the question continued to plague rowing in New Zealand throughout the twentieth century. ${ }^{85}$

Rowing was an organised sport which played a significant role in the social development of Canterbury between 1850 and 1890. Although there was a degree of friction between 'amateurs' and 'professionals' in the Province, it never assumed the proportions of the disputes which plagued English and Australian rowing. Consequently, most of the clubs, and all of the regattas, which were central to competitive rowing in the Province, remained 'inclusive' in nature and 'open' to oarsmen of all social backgrounds. Men 
from a wide variety of social backgrounds collaborated enthusiastically to arrange the regattas which consistently attracted thousands of spectators of both sexes and all ages. Rowing fostered a sustained interaction between groups and individuals from across the entire social spectrum of the settler population in Canterbury. Further research will quite possibly prove that the sport had a similar effect in other parts of New Zealand during the nineteenth century.

1 O.A. Gillespie, South Canterbury: A Record of Settlement, Timaru, 1958; W.H. Oliver, The Story of New Zealand, London, 1963; W.H. Scotter, A History of Canterbury: vol.III: 1876-1950, Christchurch, 1965; W.J. Gardner (ed.), A History of Canterbury: Vol.II: General History, 1854-76 and Cultural Aspects, 1850-1950, Christchurch, 1971; A. Grey, Aotearoa and New Zealand: A Historical Geography, Christchurch, 1994; J. Belich, A History of the New Zealanders: From Polynesian Settlement to the End of the Nineteenth Century, Auckland, 1996; K. Sinclair, A History of New Zealand, with Additional Material by Raewyn Dalziel, Auckland, 2000.

2 K. Pearson, 'Meanings and Motivation in Sport', in J. Hinchcliff (ed.), The Nature and Meaning of Sport in New Zealand, Auckland, 1978, p.9; J. Barclay, 'An Analysis of Trends in New Zealand Sport From 1840 to 1900', B.A. (Hons) extended essay, Massey University, 1977; Jock Phillips, A Man's Country? The Image of the Pakeha Male: A History, Revised Edition, Penguin Books, Auckland, 1996, pp.81-130; K. Sinclair, A Destiny Apart: New Zealand's Search for National Identity, Wellington, 1986, pp.143-55; S.A.G.M. Crawford, 'A History of Recreation and Sport in Nineteenth Century Otago', PhD thesis, University of Queensland, 1984, passim, esp. pp.56-7, 136-53.

3 N. Wigglesworth, A Social History of English Rowing, London, 1992, pp.26-8, 34-42; D. Adair, 'Rowing and Sculling', in W. Vamplew and B. Stoddart (eds), Sport in Australia: A Social History, Melbourne, 1994, p.176; E. Halladay, Rowing in England: A Social History: The Amateur Debate, Manchester, 1990, passim.

4 N. Wigglesworth, 'A History of Rowing in the North-west of England', in British Journal of Sports History, vol.3, no.3, 1986, pp.149, 152; M. Crotty, 'Rowing in Victoria, 1875-1914: A Social History', MA thesis, Monash University, Melbourne, 1996, pp.94-5.

5 Crotty, 'Rowing in Victoria, 1875-1914', pp.94-7, 178.

6 Weekly Press (WP), 6 March 1869; 22 February, 26 April 1873; Lyttelton Times (LT), 17 May 1872.

$7 \quad L T, 7,12$ December 1870.

8 LT, 29 October 1867.

9 K. McCrone, Playing the Game: Sport and the Physical Emancipation of English Women, 1870-1940, 1988, p.7; M.A.E. Hammer, " "Something Else in the World to Live For": Sport and the Physical Emancipation of Women and Girls in Auckland, 1880-1920', M.A. thesis, University of Auckland, 1990, pp.4, 144.

10 G. T. Vincent, “ "Contested By Both Whites And Maoris”: Maori and Sport in Canterbury, 1860 - 1880', forthcoming.

$11 \quad L T, 31$ May 1851.

12 LT, 11, 28 March; 24, 27, 30 April; 6, 8, 9, 16, 25, 27 May; 5 June 1867; 22 January 1868.

13 P. Wood, Kaiapoi: A Search for Identity, Rangiora, 1993, pp.73, 76.

$14 W P, 2$ September, 4 November 1871. 
15 Stevens \& Bartholomew's New Zealand Directory for 1866-67, Melbourne, 1867, p.161; New Zealand Census 1874, 1878; Geoff Vincent, "Impossibly Elistist and Snobbish": Amateurism in Canterbury, 1850-1880, The Examples of Aquatics and Athletics', in Australian Society for Sports History, Bulletin No.31, December 1999, pp.6-12.

$16 L T, 18$ May 1897.

1724 November 1868, Canterbury Rowing Club Minute Book, 18 March 1864 - 9 September 1881, M.S. 162/87, CRC 2, Canterbury Museum Library, Christchurch.

18 The following sources have been consulted in the compilation of the tables in this paper, with additional sources being utilised where appropriate: 'The Macdonald Dictionary of Biography', Canterbury Museum Library; Cyclopedia of New Zealand, vol.III: Canterbury, Christchurch, 1903; L.G.D. Acland, The Early Canterbury Runs, Christchurch, 1975; W. J. Gardner (ed.), A History of Canterbury: vol.II: General History, 1854-76 and Cultural Aspects, 1850-1950, Christchurch, 1971; G.W. Graham and L.J.B. Chapple, Ellesmere County: The Land, the Lake, and the People, 1864-1964, Canterbury, 1965; O.A. Gillespie, South Canterbury: A Record of Settlement, Timaru, 1958; W.H. Scotter, A History of Canterbury: vol.III: 1876-1950, Christchurch, 1965.

19 The term 'middling classes' was popularized by R.S. Neale in 'Class and Class Consciousness in Early Nineteenth Century England: three classes or five?', in R.S. Neale (ed.), History and Class: Essential Readings in Theory and Interpretation', Oxford, 1984, pp.143-164

20 Ibid.

21 Ibid.

$22 L T, 5$ September 1870.

$23 L T, 17$ September 1864; 30 August 1866; 2 September 1869.

$24 L T, 16$ September 1876.

25 Ibid.

$26 L T, 21$ September 1872; 7 September 1875; 6 September 1877.

27 LT, 31 August 1878, 26 August 1880, 18 September 1890.

28 MDB, passim; Cyclopedia, Canterbury, passim.

29 Electoral Rolls, 1879, passim; MDB, passim; Cyclopedia, Canterbury, passim.

30 WP, 2 December 1871.

31 E. Dunning and K. Sheard, Barbarians, Gentlemen and Players: A Sociological Study of the Development of Rugby Football, Oxford, 1979, p.148.

32 LT, 22 November 1876.

33 Ibid.

34 A. Grey, Aotearoa and New Zealand: A Historical Geography, Christchurch, 1994, p.166.

35 LT, 23 November 1876.

36 M. Crotty, 'Rowing in New Zealand to 1914: The Development of an Old World Sport in a New World Setting', B.A. (Hons) History Research Project, University of Canterbury, 1992, p.18.

37 LT, 12 September 1885; 7 September 1886; Press, 18 September 1890.

38 LT, 7 September 1874; 16 September 1876; 19 February 1878.

39 WP, 15 February 1871; 13 September 1873.

40 WP, 7 July 1877.

41 LT, 7 December 1868; 24, 28 October 1870; 13 March, 13 April, 17 May 1872; 7 September 1874, 4 November 1876.

42 LT, 17 May 1872.

43 Geoffrey T. Vincent, 'Sport, Class and Community in Canterbury, 1850-1880: The Evidence of Rowing', in Brad Patterson (ed.), Sport, Society \& Culture in New Zealand, Wellington, 1999, pp.157-64. 


\section{Journal of New Zealand Studies}

$44 L T, 2$ January 1858.

45 LT, 2 January 1864; 3 January 1865; 5 January 1867.

46 WP, 4 January 1873 ; 8 January 1876.

47 WP, 26 October 1872; 20 March 1875.

48 WP, 4 January 1868; 22 January 1870; 26 October, 28 December 1872.

49 The Press, 27 December 1864.

50 WP, 22 December 1866.

51 WP, 31 March 1877.

52 LT, 29 May 1852; 28 May 1853; 31 May 1856; 2 January 1858; 2 January 1869; WP, 28 December 1867; 11 March 1876.

$53 L T, 18$ December 1866.

$54 L T, 2$ January 1869.

55 LT, 28 September 1866.

56 S. Eldred-Grigg, A Southern Gentry: New Zealanders Who Inherited the Earth, Dunedin, 1982, p.82; LT, 31 January 1863; 12 March 1864.

57 MDB, passim; Cyclopedia, Canterbury, passim; Gardner (ed.), A History of Canterbury: vol.II, passim.

58 cf C. Toynbee, 'Class and Social Structure in Nineteenth-Century New Zealand', in New Zealand Journal of History, vol.13, no.1, April 1979, p.73.

59 LT, various dates, November - December 1880; Cyclopedia, Canterbury, passim; Electoral Rolls, 1878-9, 1879-80, 1880-1, passim; Freeholders Return, passim; Acland, The Early Canterbury Runs, passim; Gardner (ed.), A History of Canterbury: vol.II, passim.

60 LT, various dates, November - December 1869; MDB, passim; Cyclopedia, Canterbury, passim; Gardner (ed.), A History of Canterbury: vol.II, passim.

61 LT, various dates, November - December 1880; Cyclopedia, Canterbury, passim; Electoral Rolls, 1878-9, 1879-80, 1880-1, passim; Freeholders Return, passim; Acland, The Early Canterbury Runs, passim; Gardner (ed.), A History of Canterbury: vol.II, passim.

62 WP, 26 September 1874; 4 March 1876.

63 WP, 31 December 1870; 6 December 1879.

$64 L T, 23$ December 1865.

65 W.A. Pierre, Canterbury Provincial Railways: Genesis of the N.Z.R. System, Wellington, 1964, pp.24-6; Gardner (ed.), A History of Canterbury: vol.II, pp.151-5.

66 Pierre, Canterbury Provincial Railways, p.56.

67 Ibid., pp.24-6; Electoral Rolls, 1878-9, 1879-80, 1880-1, passim.

68 E. Halladay, 'Of Pride and Prejudice: The Amateur Question in English NineteenthCentury Rowing', in International Journal of the History of Sport, vol.4, no.1, May 1987, p 43.

69 The Press, 21 December 1864; WP, 31 March 1877.

70 WP, 4 January 1868; 20 March 1875.

71 The Press, 3 January 1865; LT, 23 December 1865; 10 January 1868; 4 January 1869.

$72 L T, 13$ December 1865.

73 WP, 5 January 1867; 26 December 1868; 22 January 1870; 25 March 1876.

$74 W P, 6,20$ October; LT, 28 September 1866.

$75 L T, 5$ February 1872.

$76 L T, 13$ February 1872.

$77 L T, 5$ February 1872.

78 Ibid.

$79 L T, 8$ February 1872 (italicised name in original). 
$80 L T, 6$ February 1872.

$81 L T, 9$ February 1872.

$82 L T, 7$ February 1872.

83 Another possible reason might have been to exclude crews from the highly competitive Cure Boating Club, the only club in Canterbury which contained significant numbers of blue-collar workers.

84 Crotty, 'Rowing in New Zealand to 1914', p.28.

85 E. Martin, Running Rowing: A Brief History of the Canterbury Rowing Association, 1902-2002, Christchurch, New Zealand, 2002, pp.36-41. 